the total of 1,161 sumples af cream examined in the survey by Barrow and Miller (1967) only 221 and 119 samples respectively satisfied these criteria.

The findings described in the present paper suggest that closer attention should be paid to cream, and they emphasize the need for at least clear guidance for cream producers and retailers, and for the introduction of minimum bacteriological standards for samples. We would also urge that the date of production or dispatch, and whether or not heat-treated, should be clearly marked on all retail cream containers.

\section{Summary}

During a survey in which 1,161 samples of fresh cream and cream products were examined for bacteriological quality Brucella abortus was isolated in two separate episodes from whipped cream from four out of seven fresh cream cakes. In the subsequent investigations at the bakeries and dairies concerned 19 isolations of $\mathrm{Br}$. abortus were made from various samples of cream. Both these episodes were due to insufficient heat treatment of the cream at the dairies. In one dairy the heat treatment given had been thought to be adequate; in the other dairy there were obvious faults and errors.

In the survey $\mathrm{Br}$. abortus was also isolated by direct culture from 5 out of 916 samples of clotted cream. This was presum- ably due either to survival of these organisms during heat treatment or to contamination after heat treatment.

These findings suggest that closer attention should be paid to cream as a hazard to public health, and they emphasize the need for improved legislation and for the introduction of minimum bacteriological standards for cream.

We are grateful to medical officers of health, public health inspectors, and the managers of dairies in Cornwall for help during this work.

\section{REPERENCES}

Barrow, G. I., and Miller, D .C. (1967). Mth. Bull. Minist. Hlth Lab.

Serv., 26, 254.
Barrow, G. I., and Peel, M. (1967). Mth. Bull. Minist. Hith Lab. Sero., 26, 192.

Colenso, R., Court, G., and Henderson, R. J. (1966). Mth. Bull. Minist. Hlth Lab. Serv., 25, 153.

Canadian Government Specifications Board (1964). Specification No. 32$G P-170 C$ National Research Council, Onawa.

Crossley, E. L. (1948). 7. Dairy Res., 15, 261.

Crossley, E. L. (1948). F. Dairy Res., 15, 261. (General) Regulations, 1959, at Britain (1959). The Milk and Dairies

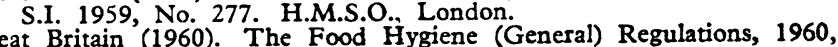
Sritain (1960), The Food Hygiene (Gen
S.I. 1960. No. 1601. H.M.S.O., London.

Great Britain (1963). The Milk (Special Designation) Regulations, 1963, S.I. 1963, No. 1571 . H.M.S.O., London.

Miles, A. A., and Misra, S. S. (1938). F. Hyg. (Lond.), 38, 732.

Northern Ireland (1966). Marketing of Milk Products Regulations, 1966. Stat. Rules and Orders No. 204. H.M.S.O., Belf ast.

Public Health Laboratory Service (1958). Mth. Bull. Minist. Hith Lab. Serv., 17, 77.

\title{
Ineffectiveness of Propranolol in Hypertensive Jamaicans
}

\author{
G. S. HUMPHREYS,* M.B., B.S., M.R.C.P., M.R.C.P.ED. ; D. G. DELVIN, † M.B., B.S., D.OBST.R.C.O.G., D.C.H.
}

Brit. med. F., 1968, 2, 601-603

It has been suggested that the $\beta$-adrenergic blocking agent propranolol is a relatively potent hypotensive agent. In order to prove or disprove this assertion 18 hypertensive Jamaicans underwent a double-blind cross-over trial, preceded by a runin period.

\section{Patients}

Of the 18 patients six (Cases 1-6) were female and 12 (Cases 7-18) were male. Each was an urban Jamaican of predominantly negro extraction. None was on any therapy before the trial, and no other drugs were used throughout. All had been under observation for long enough to ensure that they were genuinely and consistently hypertensive. Patients with heart failure, angina, asthma, a raised blood urea, grade IV retinopathy, or nephritis were excluded from the trial. Those aged 65 and over were also excluded. All patients were between 46 and 63 years old, in practice.

For the purposes of the double-blind section of the trial patients were divided into two groups of nine, each one having a partner of the same sex, age, and, so far as possible, severity of hypertension.

\section{Methods}

The trial lasted six months and was divided into three equal terms-the initial term being for run-in purposes in view of the possible danger of side-effects at high dosage. The second and third terms formed the double-blind cross-over trial.
The run-in term was, of course, uncontrolled. Patients were started on $20 \mathrm{mg}$. of propranolol four times daily, and the dosage was gradually increased over a period of a week to 40 mg. q.d.s. It was then augmented, usually at weekly intervals, still giving four doses a day, until a maximum of $360 \mathrm{mg}$. daily was reached. From this stage onwards doses were given three times a day.

Two patients were kept at $320 \mathrm{mg}$. daily because they had become transiently normotensive. In addition, two patients had their dosages reduced to $320 \mathrm{mg}$. daily, and two others to $240 \mathrm{mg}$. daily, because of possible, but very mild, sideeffects.

At the start of the double-blind terms each patient was assigned either to the drug or to an inert placebo of identical appearance and taste, the same number of tablets being given as that reached on the run-in term. Choice of therapy was made by an independent third party, who was given a list of nine pairs of ciphers and asked to assign one of each pair to the drug and the other to the placebo by random methods. At the end of the second term each patient changed over therapy for the duration of the third term. The third party was the sole possessor of the "code" until after the completion of the trial.

During the double-blind periods patients were seen at fortnightly intervals. The method of recording blood pressure was uniform throughout. Each patient was asked to lie supine for

* Consultant Physician, University of the West Indies and Kingston Public Hospital, Kingston, Jamaica, West Indies.

† Medical Registrar, Kingston Public Hospital, Kingston, Jamaica, West Indies. 
five minutes; a recording was then made, the right arm being used. He or she then stood for two minutes before the next reading was taken. These procedures were carried out without consulting the previous values recorded in the patient's notes.

All readings were made to the nearest $5 \mathrm{~mm}$. $\mathrm{Hg}$, as we do not believe that the average mercury manometer can be relied on for greater accuracy.

\section{Results}

By the end of the uncontrolled run-in period, after two months, there had been a slight overall fall in blood pressure, the average change being $-15 /-5 \mathrm{~mm}$. Hg (supine) and $-10 /-10$ (erect). What little fall did take place seemed to have occurred by about the third week.

The results of the double-blind terms of the trial are given in the accompanying Table, which compares the average systolic and diastolic blood pressures, supine and erect, on drug and on placebo.

\begin{tabular}{|c|c|c|c|c|}
\hline $\begin{array}{l}\text { Case } \\
\text { No. }\end{array}$ & $S$ or $E$ & $\begin{array}{l}\text { Propranolol } \\
\text { (A) }\end{array}$ & $\begin{array}{l}\text { Placebo } \\
\text { (B) }\end{array}$ & $\begin{array}{l}\text { Difference } \\
(\mathrm{A}-\mathrm{B})\end{array}$ \\
\hline 1\{ & $\underset{\mathrm{E}}{\mathrm{S}}$ & $\begin{array}{l}195 / 110 \\
185 / 107 \cdot 5\end{array}$ & $\begin{array}{l}225 / 115 \\
211 \cdot 25 / 116 \cdot 25\end{array}$ & $\begin{array}{l}-30 /-5 \\
-26 \cdot 25 /-8.75\end{array}$ \\
\hline & $\underset{\mathrm{E}}{\mathrm{S}}$ & $\begin{array}{l}196 \cdot 25 / 117 \cdot 5 \\
173 \cdot 75 / 121 \cdot 25\end{array}$ & $\begin{array}{l}180 / 111 \cdot 25 \\
167 \cdot 5 / 115\end{array}$ & $\begin{array}{l}+16 \cdot 25 l+6 \cdot 25 \\
+6 \cdot 25 /+6 \cdot 25\end{array}$ \\
\hline 3\{ & $\stackrel{\mathrm{S}}{\mathrm{E}}$ & $\begin{array}{l}215 / 132 \cdot 5 \\
220 / 138 \cdot 75\end{array}$ & $\begin{array}{l}211 \cdot 25 / 118 \cdot 75 \\
208 \cdot 75 / 126 \cdot 25\end{array}$ & $\begin{array}{l}+3 \cdot 75 /+13 \cdot 75 \\
+11 \cdot 25 /+12 \cdot 5\end{array}$ \\
\hline 4\{ & $\underset{\mathrm{E}}{\mathrm{S}}$ & $\begin{array}{l}218 \cdot 75 / 123 \cdot 75 \\
230 / 125\end{array}$ & $\begin{array}{l}227 \cdot 5 / 131 \cdot 25 \\
225 / 127 \cdot 5\end{array}$ & $\begin{array}{l}-8 \cdot 75 /-7 \cdot 5 \\
+5 /-2 \cdot 5\end{array}$ \\
\hline & $\underset{\mathrm{E}}{\mathrm{S}}$ & $\begin{array}{l}147 \cdot 5 / 93 \cdot 75 \\
140 / 86 \cdot 25\end{array}$ & $\begin{array}{l}170 / 103 \cdot 75 \\
158 \cdot 75 / 105\end{array}$ & $\begin{array}{l}-22.5 /-10 \\
-18.75 /-18.75\end{array}$ \\
\hline 6\{ & $\stackrel{\mathrm{S}}{\mathrm{E}}$ & $\begin{array}{l}191 \cdot 25 / 106 \cdot 25 \\
183 \cdot 75 / 107 \cdot 5\end{array}$ & $\begin{array}{l}176 \cdot 25 / 113 \cdot 75 \\
172 \cdot 5 / 113 \cdot 75\end{array}$ & $\begin{array}{l}+15 /-7 \cdot 5 \\
+11 \cdot 25 /-6 \cdot 25\end{array}$ \\
\hline 7\{ & $\underset{\mathrm{E}}{\mathrm{S}}$ & $\begin{array}{l}146 \cdot 25 / 97 \cdot 5 \\
150 / 100\end{array}$ & $\begin{array}{l}173 \cdot 75 / 101 \cdot 25 \\
168 \cdot 75 / 108 \cdot 75\end{array}$ & $\begin{array}{l}-27.5 /-3.75 \\
-18.75 /-8.75\end{array}$ \\
\hline 8\{ & $\underset{\mathrm{S}}{\mathrm{S}}$ & $\begin{array}{l}161 \cdot 25 / 106 \cdot 25 \\
163 \cdot 75 / 113 \cdot 75\end{array}$ & $\begin{array}{l}176 \cdot 25 / 120 \\
192 \cdot 5 / 132 \cdot 5\end{array}$ & $\begin{array}{l}-15 /-13 \cdot 75 \\
-28.75 /-18 \cdot 75\end{array}$ \\
\hline 9\{ & $\stackrel{S}{E}$ & $\begin{array}{l}197 \cdot 5 / 115 \\
201 \cdot 25 / 132 \cdot 5\end{array}$ & $\begin{array}{l}173 \cdot 75 / 116 \cdot 25 \\
187 \cdot 5 / 125\end{array}$ & $\begin{array}{l}+23.75 /-1 \cdot 25 \\
+13 \cdot 75 /+7.5\end{array}$ \\
\hline 10\{ & $\stackrel{\mathrm{S}}{\mathrm{E}}$ & $\begin{array}{l}166 \cdot 25 / 116 \cdot 25 \\
173 \cdot 75 / 121 \cdot 25\end{array}$ & $\begin{array}{l}168 \cdot 75 / 113 \cdot 75 \\
172 \cdot 5 / 123 \cdot 75\end{array}$ & $\begin{array}{l}-2.5 /+2.5 \\
+1 \cdot 25 /-2.5\end{array}$ \\
\hline 11\{ & $\stackrel{\mathrm{S}}{\mathrm{E}}$ & $\begin{array}{l}150 / 108 \cdot 75 \\
148 \cdot 75 / 116 \cdot 25\end{array}$ & $\begin{array}{l}165 / 115 \\
158 \cdot 75 / 120\end{array}$ & $\begin{array}{l}-15 /-6 \cdot 25 \\
-10 /-3.75\end{array}$ \\
\hline 12\{ & $\underset{\mathrm{E}}{\mathrm{S}}$ & $\begin{array}{l}243 \cdot 75 / 145 \\
245 / 152 \cdot 5\end{array}$ & $\begin{array}{l}222 \cdot 5 / 146 \cdot 25 \\
228 \cdot 75 / 155\end{array}$ & $\begin{array}{l}+21 \cdot 25 /=1.25 \\
+16 \cdot 25 /=2.5\end{array}$ \\
\hline 13\{ & $\stackrel{\mathrm{S}}{\mathrm{E}}$ & $\begin{array}{l}230 / 153 \cdot 75 \\
220 / 152 \cdot 5\end{array}$ & $\begin{array}{l}202 \cdot 5 / 130 \\
210 / 140\end{array}$ & $\begin{array}{l}+27 \cdot 5 /+23 \cdot 75 \\
+10 /+12 \cdot 5\end{array}$ \\
\hline 14 & $\mathrm{~S}$ & $\begin{array}{l}155 / 105 \\
147 \cdot 5 / 103.75\end{array}$ & $\begin{array}{l}165 / 111 \cdot 25 \\
155 / 111 \cdot 25\end{array}$ & $\begin{array}{l}-10 /-6 \cdot 25 \\
-7 \cdot 5 /-7 \cdot 5\end{array}$ \\
\hline 15\{ & $\mathrm{S}$ & $\begin{array}{l}148 \cdot 75 / 101 \cdot 25 \\
145 / 107 \cdot 5\end{array}$ & $\begin{array}{l}157 \cdot 5 / 113 \cdot 75 \\
165 / 116 \cdot 25\end{array}$ & $\begin{array}{l}-8.75 /-12.5 \\
-20 /-8.75\end{array}$ \\
\hline 16\{ & $\underset{\mathrm{E}}{\mathrm{S}}$ & $\begin{array}{l}226 \cdot 25 / 145 \\
201 \cdot 25 / 148 \cdot 75\end{array}$ & $\begin{array}{l}205 / 142 \cdot 5 \\
207 \cdot 5 / 142 \cdot 5\end{array}$ & $\begin{array}{l}+21 \cdot 25 /+2 \cdot 5 \\
-6 \cdot 25 /+6 \cdot 25\end{array}$ \\
\hline 17 & $\stackrel{\mathrm{S}}{\mathrm{E}}$ & $\begin{array}{l}181 \cdot 25 / 115 \\
180 / 117 \cdot 25\end{array}$ & $\begin{array}{l}172 \cdot 5 / 117 \cdot 5 \\
175 / 116 \cdot 25\end{array}$ & $\begin{array}{l}+8 \cdot 75 /-2 \cdot 5 \\
+5 /+1\end{array}$ \\
\hline 18\{ & $\underset{\mathrm{E}}{\mathrm{S}}$ & $\begin{array}{l}221 \cdot 25 / 141 \cdot 25 \\
222 \cdot 5 / 138 \cdot 75\end{array}$ & $\begin{array}{l}190 / 116 \cdot 25 \\
198 \cdot 75 / 120\end{array}$ & $\begin{array}{l}+31 \cdot 25 l+25 \\
+23 \cdot 75 !+18 \cdot 75\end{array}$ \\
\hline
\end{tabular}

The paired comparison test was applied to the differences between the two sets of figures, with the following results:

Supine B.P., systolic: $t=0.344$ (not significant, $P=0.37$ )

Supine B.P., diastolic: $t=0.079$ (not significant; $\mathrm{P}=0.50$ )

Erect B.P., systolic: $t=0.488$ (not significant ; $P=0.32$ )

Erect B.P., diastolic: $t=0.55$ (not significant; $\mathrm{P}=0.28$ )

There was thus no significant difference between the effect of the drug and that of the placebo.

\section{Side-effects}

Subjective side-effects were remarkably few, considering that the dosage levels were rather higher than those usually given. In particular, no ill effects whatever were noted in those patients who had placebo tablets in the second term and propranolol in the third, and who thus went directly from no propranolol to $360 \mathrm{mg}$. daily on the first day of the third term. We make no apologies for adopting this procedure, which we feel to be without risk in properly selected patients who are kept under careful observation, and who have previously been exposed to the same dose of the drug without ill effects.

During the run-in term we were not convinced that any symptoms reported were necessarily due to propranolol. However, four patients did have their dosage reduced as a precautionary measure, and the symptoms complained of rapidly disappeared. These possible side-effects were: both headache and insomnia (two patients), palpitations (one patient), and "low feelings"-a local term with a multiplicity of meaningsby one patient.

That only four patients out of 18 complained of anything at all during the run-in term seemed to indicate a very low incidence of side-effects, and this was confirmed by a review of the double-blind terms; these showed that the drug had, in fact, done slightly "better" than the placebo in this respect, being associated with one complaint of feelings of faintness, one of headache, and one of mild pruritus. The placebo, however, was associated with three complaints of palpitations and one of headache.

E.C.G.s and haemoglobin, W.B.C., urea, and S.G.P.T. estimations showed no significant changes throughout. There were several isolated rises in S.G.O.T. levels, on both drug and placebo, of the type described by Grant and Green (1964), Kernohan and Neely (1964), Tsolakas et al. (1964), and Gillam and Prichard (1965).

\section{Discussion}

It has been suggested that propranolol is a hypotensive agent of potency comparable to that of methyldopa, guanethidine, and bethanidine (Prichard and Gillam, 1966). Such has not been our experience in this, the first double-blind trial of the drug in hypertension.

There is no therapeutic value in the small overall fall in blood pressure shown during the uncontrolled run-in term. Some fall would be expected in any hypertensive group suddenly subjected to a gratifying amount of intensive investigation. In addition, both observers believed they were using a potent hypotensive agent.

A recognized hazard in Jamaica is that the patients may not really be taking the tablets, but in this trial all patients had their pulse rate noted (after the blood pressure was recorded, and without comparison at any time with previous pulse rates); and after the trial a review showed that pulse rates were normally about $8-10$ beats per minute slower while on the drug. Of course, this does not prove that the patients were taking the full dosage.

It has been suggested that the drug may have a "carryover" effect after cessation of treatment, but comparison of the average of the last two blood pressure readings in each period still falls far short of showing any significant difference, so that any carry-over would have to last at least two months. This difficulty could be resolved if in future trials the doubleblind periods were longer.

In addition to these qualifications we should stress that our results apply only to Jamaican patients, and that most previous work seems to have been done on Europeans.

The pattern of hypertension in Jamaica is not that of European communities, nor is it that of negroes living in North America, whose blood pressures tend to be higher than those of whites. There is some evidence that Jamaicans occupy an intermediate position on the scale. Rural people, especially females, are more severely afflicted than inhabitants of Kingston (Miall et al., 1962). We might surmise that these differences are due to racial background, most rural people being almost entirely of African extraction, while a Kingstonian, though usually predominantly negroid, may well also be part British, part Indian, and part Chinese in ancestry. None of our patients appeared to be of completely African extraction. 
A particular difference from European communities is that we have the distinct impression that stress is not an important factor here-we rarely see the hypertensive with "executive stress," so frequently encountered elsewhere. It has always been difficult to explain the apparent hypotensive effect of propranolol on pharmacological grounds, and it could be that the mild tranquillizing effect attributed to it is responsible. Such an effect might have little action on the blood pressures of Jamaicans; it is noteworthy that we scarcely ever use phenobarbitone as a hypotensive here.

We do not think that there is any justification for using propranolol as a hypotensive agent at the present time, but there is an obvious and immediate need for a properly controlled trial in European patients, preferably for a longer period than that of our own trial.

\section{Summary}

Eighteen hypertensive Jamaicans underwent a double-blind cross-over trial of propranolol in order to prove or disprove the assertion that the drug is a relatively potent hypotensive agent.

Though the dosage used was high there was no significant difference in effect between the drug and an inert placebo. It is suggested that this may have been so because the "tranquillizing " effect of the drug is unlikely to be of value in Jamaican hypertensive patients.

We stress that our conclusions do not necessarily apply to European patients, in whom a properly controlled trial is urgently needed, preferably for longer periods of therapy to exclude any possible "carry-over" effect.

Propranolol in high dosage is remarkably free from sideeffects when given to carefully selected patients.

We should like to express our thanks to Imperial Chemical Industries, Ltd., and in particular to Mr. Timothy Wortman, for assistance and for the supply of placebo tablets and of propranolol (Inderal). Our thanks also go to our patients; to the Jamaican Ministry of Health for permission to publish this paper; to Staff Nurses Tulloch, Samuels, Brown, and Distant, of the Kingston Public Hospital; and to Miss Ruth Bell, of the M.R.C., for statistical advice.

\section{RBFERENCES}

Gillam, P. M. S., and Prichard, B. N. C. (1965). Brit. med. F., 2, 337. Grant, R. H. E., and Green, K. G. (1964). Lancet, 2, 1240.

Kernohan, R. J., and Neely, R. A. (1964). Lancet, 2, 1338.

Miall, W. E. Kass, E. H., Ling, J., and Stuart, K. L. (1962). Brit. med. Y., $2,497$.

Prichard, B. N. C., and Gillam, P. M. S. (1966). Lancet, 2, 1317.

Tsolakas, T. C., Davies, J. P. H., and Oram, S. (1964). Lancet, 2, 1064.

\section{Medical Memoranda}

\section{Double Charcot's Disease}

\section{Brit. med. F., 1968, 2, 603-604}

Charcot's arthropathy (Charcot, 1868) is usually asymmetrical, with gross destruction, disorganization, and often dislocation (or subluxation) of a joint, associated with disproportionately mild discomfont, exuberant bony overgrowth, and synovial effusion.

Charcot and Marie (1886) in Paris, and Tooth (1886) independently in Cambridge, described a syndrome in which wasting and weakness started in the lower limbs, affecting predominantly the peronei, anterior tibials, and small muscles of the feet, and slowly spread proximally. The wasting stopped abruptly in a transverse line across the lower part of the thigh, giving the " inverted champagne bottle" appearance. Several years later weakness and wasting occurred in the hands and forearms. The onset of the disease was usually in early childhood or adolescence, and the condition was found to be hereditary in most cases.

This paper provides the first report in the English literature of a case in which Charcot's arthropathy is attributable to Charcot-Marie-Tooth disease.

\section{CASE REPORT}

A 58-year-old male caretaker had suffered from weakness of his feet since the age of 9 years and weakness of his hands which started two or three years later. He noticed numbness of his limbs a few years after the onset of the weakness. Both weakness and numbness had progressed steadily throughout his life, but more rapidly in the previous two years. Recently the ground had felt less solid when he walked and his gait had been unsteady.

At the age of 14 he fractured his right ankle, but subsequently had no joint symptoms until the age of 40 , when his left ankle began to swell, and eight years later, when swelling started in his right ankle. The ankles ached a little after exercise but were never painful. A few weeks before he was seen at the Middlesex Hospital, in October 1966, he developed an ulcer on the sole of his left foot. There was no family history of neurological disorder.

On examination no abnormalities were found in the cranial nerves. In particular, the fundi were normal and there was no nystagmus. There was some wasting and weakness of all the small muscles of both hands and weakness without wasting of the long wrist and finger extensors. "There was no intention tremor. Muscle tone was diminished. There was symmetrical wasting of the small foot muscles, calves, and, to a less extent, the lower third of the thighs (Fig. 1). Complete paralysis of the peronei was present on both sides, and almost complete paralysis of the anterior tibial muscles and the intrinsic muscles of both feet. Muscle tone was diminished. There was no abnormality of the trunk and limb girdle musculature and no ataxia in the heel-knee test. All tendon reflexes in the limbs were absent and plantar responses were flexor. Pain sensation was absent to pin-prick, and appreciation of light touch and temperature was reduced in a stocking distribution to the mid-calf. No pain was aroused by pinching the tendo Achillis. Vibration sense was diminished over the pelvis and absent at the knees, ankles, and toes. Joint position sense was severely impaired at the toes and to a lesser degree at the ankles. In the upper limbs sensation to light touch, pain, and temperature was reduced in a glove distribution to above the wrist. Vibration sense was absent in the fingers and 